\title{
Ripening-related changes in Serra da Estrela cheese: A stereological study
}

\author{
P. J. M. Reis ${ }^{\star}$ and F. X. Malcata†‡ $\S^{1}$ \\ ${ }^{*}$ CBQF/Escola Superior de Biotecnologia, Rua Dr. António Bernardino de Almeida, P-4200-072 Porto, Portugal \\ †Instituto Superior da Maia, Avenida Carlos Oliveira Campos (ISMAI), P-4475-690 Avioso S. Pedro, Portugal \\ ¥Centro de Biotecnologia Agrícola e Agro-Alimentar do Baixo Alentejo e Litoral (CEBAL), Rua Pedro Soares, Apartado 6158, \\ P-7801-908 Beja, Portugal \\ SInstituto de Tecnologia, Química y Biológica, Universidade Nova de Lisboa, Avenida da Republica, P-2780-157, Oeiras, Portugal
}

\section{ABSTRACT}

Despite its relevance to sensory features and to fundamental explanation of the changes observed throughout cheese ripening, microstructural studies of specialty cheeses have lagged far behind those of industrialized cheeses. Hence, the purpose of this study was to pinpoint microstructural differences in the gel network of traditional Serra da Estrela cheese throughout ripening, using 2-dimensional image analysis, and to unfold correlations of such microstructural indicators with classical bulk chemical and textural parameters. Hence, samples were taken throughout the ripening period, following a nested design; uniform thin sections were systematically observed via light microscopy (LM, 200 $\times$ ) and transmission electron microscopy (TEM, 4,400 $\times$ ), and computer-assisted quantitative analysis of digital images was comprehensively performed following standard stereological methodology. Fresh cheeses exhibited the highest porosity and ratio of surface area to volume. Significant negative correlations were found between microstructural parameters and proteolysis indicators. Light microscopy images suggested that rearrangements exist, up to $21 \mathrm{~d}$, of the cheese matrix that leave porosity and pores unchanged, whereas TEM images indicated a significant decrease in number of pores within the same time frame, especially those above $1 \times 10^{-2} \mu \mathrm{m}^{2}$ in area. The larger pores, chiefly with cross-sectional areas above $40 \mu \mathrm{m}^{2}$, were less represented by the end of ripening - and likely explain the observed significant decrease of cheese porosity without a change in number of pores. Field viewing significantly affected the microstructural parameter values, whereas section viewing affected significantly only LM-based ones. Categorical principal component analysis between the 2 types of microstructural data sets was performed, and permitted discrimination of each stage of ripening. Multiple linear regression analysis indicated that

Received May 7, 2010.

Accepted October 24, 2010.

${ }^{1}$ Corresponding author: fmalcata@ismai.pt the variables associated with the nitrogen fraction were well predicted by stereological-based parameters $\left(\mathrm{R}^{2} \geq\right.$ $0.96)$. Therefore, our findings demonstrate the potential of image analysis to monitor microstructure throughout ripening, and that the microstructure revealed by LM reflects more clearly cheese aging than that revealed by TEM.

Key words: light microscopy, transmission electron microscopy, microstructure, pore size distribution

\section{INTRODUCTION}

Over the last 2 decades, Serra da Estrela, the most famous and unique Portuguese cheese, has been investigated, aiming not only at its technological optimization, but also at a better fundamental understanding of its microbiological, physicochemical and rheological evolution during ripening (Macedo et al., 1993, 1996; Tavaria and Malcata, 1998; Tavaria et al., 2003); however, a knowledge gap relating to its microstructure remains. Parker et al. (1998) originally used light and electron microscopies to ascertain the distribution of microorganisms within mature Serra da Estela cheese, whereas more recently Tavaria et al. (2006) attempted to correlate microbiological data with scanning electron micrographs of cheeses manufactured in distinct dairy farms (including cheesemaking milk subjected to previous refrigeration). Despite these efforts, there is still a lack of information on how microstructure evolves throughout ripening of this cheese - especially on the relationships between the porous nature of the curd network and the classical indices of proteolysis.

Microimaging of cheese has been described by several authors, using transmission electron microscopy (TEM; Tamime et al., 1999; Kheader et al., 2002), scanning electron microscopy (Rodríguez et al., 1999; Sipahioglu et al., 1999; Özer et al., 2003), and confocal light microscopy (LM; Pavia et al., 1999; Guinee et al., 2000; Buffa et al., 2001; O'Reilly et al., 2002). It is indeed generally accepted that food texture relates directly to microstructure, which, in turn, is determined by chemical composition. During ripening of Serra da 
Estrela cheese in particular, extensive changes occur in terms of proteolysis (Macedo and Malcata, 1997; Tavaria et al., 2003) that eventually determine texture, which evolves toward a rather soft and buttery one. Primary proteolysis brought about by plant rennet enzymes is believed to play a fundamental role in changes of cheese texture early in ripening, by disrupting the relatively extensive network of $\alpha_{\mathrm{s} 1}$-casein in the fresh curd (Creamer and Olson, 1982; Fox et al., 1993; Johnston et al., 1994; Watkinson et al., 2001). However, details on the relationship between changes in cheese structure during ripening and texture are scant, so efforts to help improve the quality of such a complex and heterogeneous dairy product still rely on essentially empirical approaches.

Microscopy provides rich qualitative information about the microstructure of cheese and changes thereof during ripening, but this type of information is often hard to quantify; comparisons between samples, as well as attempts to rationalize textural development based on morphology of the protein network, are, thus, difficult. On the other hand, design-based techniques have been made available in recent times, which enable estimates of germane parameters (e.g., number, length, area, and volume of pores) to be determined, while allowing quantification of arbitrary-shaped features in sections. These stereological methods include unbiased sampling schemes in combination with geometric probes (e.g., points, lines, and planes) to quantify firstand second-order stereological parameters, and do not require simplistic assumptions relating to the shape of the pore network. Three-dimensional interpretation of the 2-dimensional (2D) images obtained by microscopy is then possible, based on the stereological concept (Gundersen et al., 1988a). Choice of an appropriate grid is primarily dictated by the need for isotropic, uniform, and random sampling of the microstructure. If isotropy occurs, then any array of lines provides an unbiased sample; however, if the matrix is anisotropic, then the grid should guarantee uniform sampling in all directions. For vertical sections, either cycloid grids or lines that are sine-weighted, rather than randomly orientated, are required (Baddeley et al., 1986; Mouton, 2002; Russ, 2005). If the sample is assumed to be random, isotropic, and uniform, then any sample, section, and image can be used, and it is sufficient to examine enough fields of view to obtain adequate statistical precision.

To date, approaches using stereological concepts have been applied with success to a few cheeses (Guinee et al., 1995; Wium et al., 2003; O'Mahony et al., 2005), as well as particulate whey protein gels (Langton and Hermansson, 1996), stirred yogurt (Skriver et al., 1997), mayonnaises (Langton et al., 1999), pasta dough
(Thorvaldsson et al., 1999), whipped cream (Smith et al., 1999), apple cubes (Funebo et al., 2000), gelatin/ maltodextrin systems (Lorén et al., 1999; Hermansson et al., 2000), $\beta$-LG/amylopectin gels (Olsson et al., 2002), micellar casein gels (Auty et al., 2005), and baked bread (Datta et al., 2007) to obtain representative measures of 3-dimensional structures from these samples. To our knowledge, the only study that focused on the relationship between textural properties and microstructural data generated via image analysis during cheese maturation was carried out by O'Mahony et al. (2005); and none has ever investigated such a unique (and traditional) cheese as Serra da Estrela in this regard.

Hence, the major objective of this research effort was to find relationships between microstructural parameters and age-related physicochemical changes in ovine Serra da Estrela cheese. To this goal, stereological estimates were produced, and used to generate quantitative information on its 3 -dimensional network.

\section{MATERIALS AND METHODS}

\section{Cheesemaking and Sampling}

Two independent batches of Serra da Estrela cheese were manufactured from raw ewe's milk, following the conventional protocol approved by the regulatory board of its Appéllation d'Origine Protegée status (Macedo et al., 1993). Milk was warmed to $32^{\circ} \mathrm{C}$, and then coagulated for $45 \mathrm{~min}$ using a mixture of macerated thistle flower (Cynara cardunculus L., added at a rate of 0.2 $\mathrm{g}$ per $\mathrm{L}$ of milk) and salt (added at a rate of $20 \mathrm{~g}$ per L of milk). Afterward, the curd was cut into small particles, using knives in a circular movement. Ten minutes later, the curds were placed in a cheesecloth, and pressed manually to aid in whey expression. Drainage of whey was completed via pressing the fresh cheese in a pneumatic press, at $250 \mathrm{kPa}$ for $4 \mathrm{~h}$. The cheeses were ripened for $60 \mathrm{~d}$ : they were first kept at $8^{\circ} \mathrm{C}$ and a relative humidity of $99 \%$ for $3 \mathrm{wk}$, and then at $11^{\circ} \mathrm{C}$ and a relative humidity of $85 \%$ for the remaining time. Two independent cheeses were selected at random at each of 3 ripening times $(1,21$, and $60 \mathrm{~d})$, so 4 true replicates were subjected to chemical, rheological, and microstructural analyses.

\section{Chemical Analyses}

The determination of moisture, fat, salt, titratable acidity, $\mathrm{pH}$, and protein contents, as well as total nitrogen, water-soluble nitrogen (WSN), trichloroacetic acid-soluble nitrogen (TCASN) and phosphotungstic 


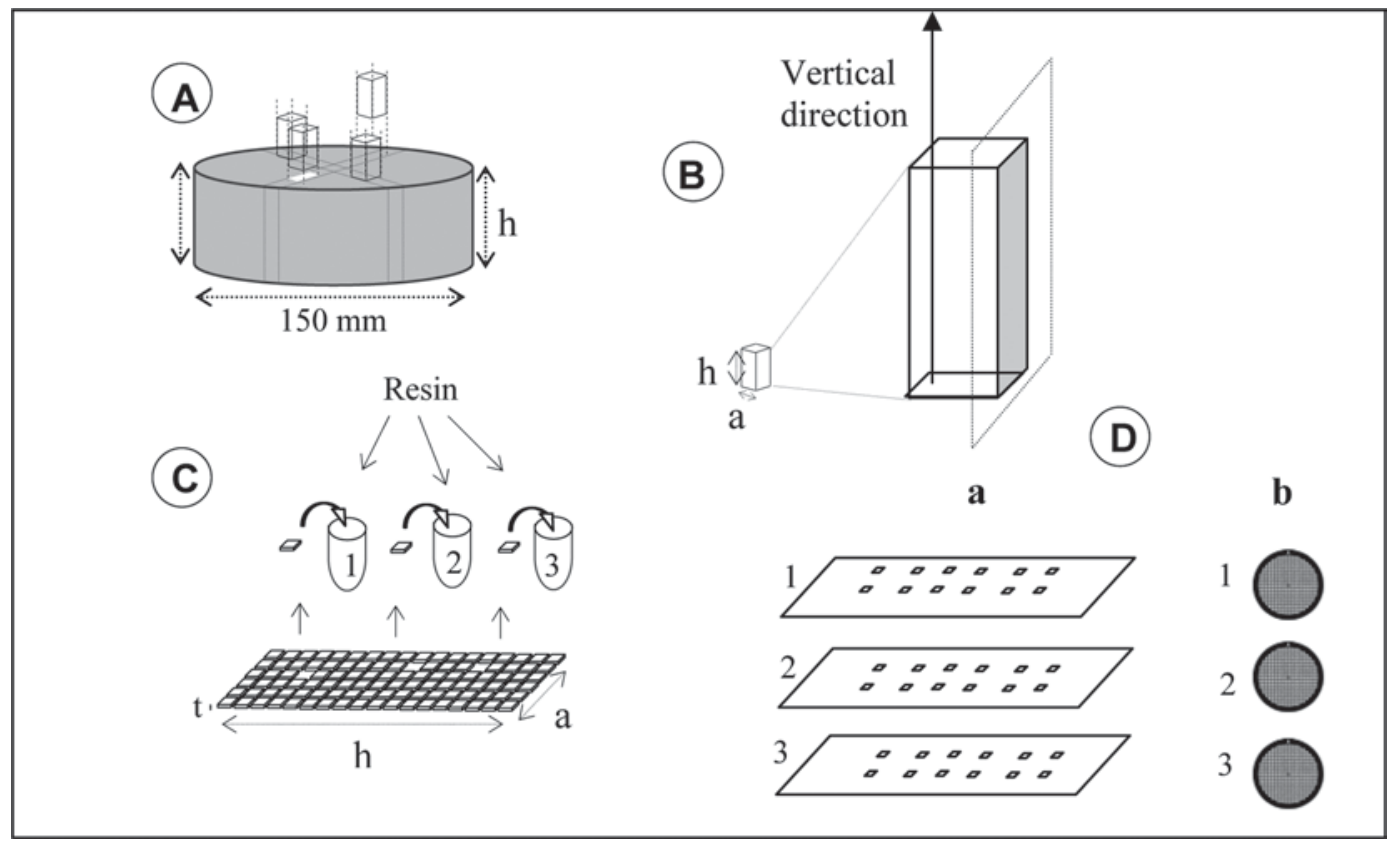

Figure 1. Sequence of sampling procedures encompassing cheese sections. (A) Parallelepipedal blocks are taken at random from cheese (a $\times$ $\mathrm{a} \times \mathrm{h}$ ); (B) sections (ca. 1-mm thick, t) are cut parallel to the vertical axis; (C) small sections are taken at random and embedded in fixed resin; and (D) semi-thin $(0.4 \mu \mathrm{m})$ sections are placed on slides for observation by light microscopy (a), and ultra-thin (70 $\mathrm{nm})$ sections are placed on copper grids for observation by transmission electron microscopy (b).

acid-soluble nitrogen (PTASN) were described in detail elsewhere (Reis et al., 2000). All analyses were performed in duplicate.

\section{Rheological Analyses}

Each cheese sample was taken at random from each of the true cheese replicates, and kept at $20^{\circ} \mathrm{C}$ for $1 \mathrm{~h}$ before analysis. Texture profile analysis was performed on the cheese surface, using a texture analyzer TA-XT Plus (Stable Micro Systems, Surrey, UK) connected to a 2-mm probe. Each test was conducted as 2 sequential penetration events, of $20-\mathrm{mm}$ penetration at a rate of $0.83 \mathrm{~mm} / \mathrm{s}$, separated by a rest period of $10 \mathrm{~s}$. The tests generated a force-time curve, from which fracturability, firmness, cohesiveness, adhesiveness, springiness, gumminess, chewiness, and Young's modulus were automatically calculated. All analyses were performed in quintuplicate.

\section{Sample Preparation for Microscopic Analyses}

Cheese samples were examined for their microstructure using LM and TEM. Blocks of cheese $(10 \times 10$ $\times 20 \mathrm{~mm}$ ) were taken with a trier inserted vertically through the cheeses from their top surface (see Figure 1 ); those samples were completely submerged in $4 \%$ (vol/vol) formalin, and fixed for at least 1 mo before cutting (Parker et al., 1998). These blocks were then cut into vertical sections, of approximately $2 \times 2 \times 1$ $\mathrm{mm}$, postfixed in $1 \%$ (wt/vol) osmium tetroxide, dehydrated using a graded ethanol series (10 to 100\%), and placed in a transitional solvent (propylene oxide). Infiltration with resin was sequentially performed using a mixture of Epon 812 (TAAB Laboratories, Berkshire, UK):propylene oxide at 1:50 for $6 \mathrm{~h}, 75: 25$ for $6 \mathrm{~h}$, and finally 100:0 overnight in a refrigerator. On the next day, the Epon was replaced by fresh Epon, and left for an extra $8 \mathrm{~h}$; finally, the samples were placed in Epon gelatin capsules, which were polymerized for ca. $48 \mathrm{~h}$ at $55^{\circ} \mathrm{C}$. Semi-thin sections (approximately $0.25 \mu \mathrm{m}$ in thickness) for LM and ultra-thin sections (approximately $0.06 \mu \mathrm{m}$ ) for TEM were cut using an LKB 8800 ultramicrotome (LKB, Bromma, Sweden), equipped with glass and diamond knives, respectively.

The aforementioned semi-thin sections were collected in (filtered) pure water, stained using a 1:1 mixture of $1 \%$ toluidine blue and $1 \%$ sodium borax to visualize the protein phase, and mounted on glass microscope slides (see Figure 1). Such sections were then covered with a cover glass and examined with an Olympus BH-2 microscope (Olympus, London, UK), fitted to a Sony XC 77 camera (Sony, Tokyo, Japan). The ultra-thin sections were, in turn, collected on copper grids (see Figure 1), and contrasted with $2 \%$ of uranyl acetate for $7 \mathrm{~min}$, followed by lead citrate for another $5 \mathrm{~min}$ 
(Reynolds, 1963); examination and image acquisition proceeded afterward with a Zeiss AxioCam (Carl Zeiss, Oberkochen, Germany), fitted to a Zeiss EM 902A TEM (Carl Zeiss) at $50 \mathrm{kV}$.

For image analysis, independent nonoverlaping LM and TEM micrographs (characterized by $1,280 \times 1,024$ and $1,294 \times 1,020$ pixels, respectively) were acquired at $200 \times$ and $4,400 \times$ magnifications, respectively, thus yielding a resolution of $0.333 \mu \mathrm{m} /$ pixel and $7.54 \mathrm{~nm} /$ pixel, respectively (see Figure 2). The relevant image parameters (described below) were then estimated for each micrograph, and averaged among micrographs pertaining to each cheese age.

\section{Image Analysis and Stereological Procedures}

Quantitative measurements were made along vertical sections, via a stereological method and then subjected to image analysis using Fovea Pro v. 3.0 software (Reindeer Graphics, Ashville, NC) with Adobe Photoshop v. 7.0 (Adobe Systems, San Jose, CA) as the host program. Said measurements were performed on LM and TEM binary images created by simple thresholding, using a gray-level established after examination of the histogram of gray-level values of the image at stake. From each semi-thin (and ultra-thin) section, every 8th (or every 6th) field was systematically sampled, and 3 stereological measures were taken on each image (relating to a field): $\mathbf{A}_{\mathbf{A}}$, the area fraction of the nonprotein phase, which is related to the void fraction; $\mathbf{P}_{\mathbf{L}}$, half of the surface area/volume ratio; and $\mathbf{L}_{\mathbf{3}}$, the mean intercept length. The binary image was thereafter skeletonized and pruned; on this latter representation, 3 structural parameters were further measured: ratio of protein skeleton length to area (hereafter, length), ratio of node count to area (hereafter, nodes), and ratio of ends count to area (hereafter, ends; see Figure 3).

All stereological measurements were taken in between 6 and 8 systematic random microscopic fields, within 3 random sections taken from 2 or 3 cheese blocks of each cheese (thus leading to either 9 or 6 analytical replicates, respectively). Arithmetic means and standard errors were determined as appropriate.

\section{Statistical Analyses}

Nonprotein phase densities, obtained via the profile counting method, and skeleton data and estimated volume-weighted mean volume, obtained via the stereological point-sampled intercepts method, were all analyzed using 3-level, nested ANOVA (with time, block nested within time, and section nested within block as parameters), in an attempt to ascertain the significance of differences, as well as the intensity of variation within and between microscopic fields, sections, and blocks. A mixed model was accordingly applied, with block and section treated as random factors, and time considered as fixed factor. Blocks and sections were randomly sampled, so their interactions with treatments were also considered as random effects. The variability among sections, the variability among blocks and the variability among ripening times were consequently estimated. Finally, principal component analysis (PCA) was used to reduce the information conveyed by the too large number of microstructural variables considered, to the level of only essential information, and to describe their interrelation pattern, as well as their putative relationships with cheese aging.

The hypothesized correlations between cheese proteolytic indices and microstructural parameters were assessed by regression analysis. For multiple regressions, and to optimize the number of variables included in the model, the backward selection method was pursued. Multicollinearity may be present when the independent variables are highly correlated with each other; in such a case, even though the coefficient of determination $\left(\mathrm{R}^{2}\right)$ values look good, the parameter estimates may change erratically in response to small alterations of the model or disturbances of the data; hence, a principal component regression analysis was performed (Liu et al., 2003) in attempts to anticipate (and overcome) this problem, as the regression equation will be built upon a set of essentially uncorrelated regressors. The principal component scores of the variables included in the model were thus used as regressors, and the proteolytic variables as functions; and nonsignificant score values were excluded from the model by a stepwise methodology. Student's tests were used to assess the regression coefficients. Finally, the coefficient of determination was used as criterion for success of the prediction model.

All statistical analyses were conducted with SPSS v. 16.0 (SPSS, Chicago, IL), and the level of significance was arbitrarily set at 0.05 (or 0.01 or even lower, as appropriate).

\section{RESULTS AND DISCUSSION}

\section{Microstructural Profile}

The microstructure of Serra da Estrela cheese was assessed at different levels by LM and TEM (see Figure 2 ). Irrespective of magnification, these micrographs show a continuous, yet irregular protein phase as a black background; and a nonprotein phase, represented in white, which includes void spaces, namely those resulting from spaces previously occupied by fat globules or gas bubbles. From these typical (and many other) micrographs, the microstructural properties of 
the cheese matrices were analyzed at various ripening times, namely in terms of number of pores per unit area, fraction of nonprotein phase, and contact area between nonprotein and protein phases. It should be noted that void space appears as patches, which can represent single pores or a network of pores connected to each other. The corresponding stereological parameters, obtained from LM and TEM images of cheese samples, are tabulated in Table 1; note that the 6 (or 9) analytical replicates referred to are actually averages of 36 (or 72) fields of view each, as required for a representative and meaningful statistical analysis.

The average size of the pores was evaluated via $\mathrm{L}_{3}$; this is a unique assumption-free value, which is valid for particles/channels of any size and configuration. As shown in Table $1, \mathrm{~L}_{3}$ values based on LM images were, on average, $2.70 \pm 0.04,2.90 \pm 0.06$, and $2.74 \pm 0.05$ $\mu \mathrm{m}$, for samples taken at 1,21 , and $60 \mathrm{~d}$, respectively. Although $\mathrm{L}_{3}$ appeared higher by $21 \mathrm{~d}$, such a difference was not significant $(P>0.05)$. Likewise, the ripening time played no significant effect on the number of pores if based on LM images; this is likely a consequence of the great variability among consecutive images, which accounted for 74.5 and $65.2 \%$ of $\mathrm{L}_{3}$ and number of pores, respectively.

In our study, $\mathrm{A}_{\mathrm{A}}$ relates to the space occupied by the nonprotein phase in the cheese matrix; it is given by the volume fraction, as cheese samples were analyzed by stereological design-based methods (Gundersen et al., 1988b). Inspection of Table 1 indicates that the area fraction underwent a decreasing trend along ripening time with statistically significant differences $(P<$ 0.05 ) between 21 and $60 \mathrm{~d}$ in the case of LM data, and between $1 \mathrm{~d}$ and later times $(21-60 \mathrm{~d})$ in the case of TEM data. These findings indicate that porosity was lowest in cheeses by $60 \mathrm{~d}$ of ripening, so an increase in protein phase density apparently took place as time elapsed. This microstructural feature is consistent with the evolution of moisture content of cheeses $(\mathrm{r}=0.738$, $P<0.01$ ): once again, no significant changes were observed in moisture content during the first $21 \mathrm{~d}$ of ripening (within 55-54\%), but the moisture decreased significantly afterward $(P<0.05)$, from $54.0 \%$ by $21 \mathrm{~d}$ to $47.0 \%$ by $60 \mathrm{~d}$ of ripening.

The frequency of pores in cheese, sorted by increasing area, is plotted in Figure 4A for 3 times of ripening (note that the pores with areas above $40 \mu \mathrm{m}^{2}$ were not considered in Figure 4A, so the cumulative values do not add up to 100\%). From the 2D LM images, one realizes the importance of the pores ranging between 1 and $5 \mu^{2}$ (which account for ca. $45 \%$ of the total pores), even though they represent only 3 to $4 \%$ of the cheese porosity; this happens because few large pores account for most void volume. In terms of number of pores, ripening time played a significant $(P<0.05)$ role in almost all pore classes; significant statistical differences were indeed found when the percents of each pore class by $1 \mathrm{~d}$ were compared with their $21-\mathrm{d}$ counterparts. As apparent in Figure 4A, pores with areas smaller than $5 \mu^{2}$ decreased in number from 1 to $21 \mathrm{~d}$, whereas those with areas between 5 and 40 $\mu \mathrm{m}^{2}$ (i.e., ca. $40 \%$ of the pores) increased in number. This observation is consistent with their contribution to cheese porosity: pores with areas greater than 40 $\mu \mathrm{m}^{2}$ increased significantly in number from 1 to $21 \mathrm{~d}$ $(P<0.05)$, despite representing only $15 \%$ of the pores, so their contribution to porosity decreased (data not shown). These trends suggest a rearrangement of the cheese matrix from 1 to $21 \mathrm{~d}$, without changes in terms of pores or porosity; however, $\mathrm{P}_{\mathrm{L}}$ decreased significantly $(P<0.05)$ throughout ripening time.

From 21 to $60 \mathrm{~d}$, the pores seemed to become smaller, on average. Despite the behavior of pores with areas below $1 \mu^{2}$, the contribution of all pore classes to porosity was statistically different by $60 \mathrm{~d}$ relative to that by $21 \mathrm{~d}$ : an increase in the number of pores smaller than $20 \mu^{2}$ was indeed observed, with a concomitant decrease in the numbers belonging to the other classes. The significant decrease of the fraction of larger pores, especially those above $40 \mu^{2}$ (which account for ca. $75 \%$ of porosity), might explain the significant decrease in cheese porosity without a relevant change in number of pores.

Based on TEM images, one concluded that ripening time had essentially no effect $(P>0.05)$ upon cheese microstructure, except with regard to pores $(P<0.05$; see Table 1). No statistically significant differences were found in terms of porosity between 1 and $21 \mathrm{~d}$, but the number of pores was lower by $21 \mathrm{~d}$ than by $1 \mathrm{~d}$; hence, some pores grew along that period. The results depicted in Figure 4B indicate clearly a larger increase of pores in the classes below $1 \times 10^{-2} \mu^{2}$, which was particularly significant $(P<0.05)$ in the case of pores with areas ranging from $0.10 \times 10^{-2}$ to $0.55 \times 10^{-2} \mu^{2}$. Conversely, the decrease in number of pores in the classes above $1 \times 10^{-2} \mu \mathrm{m}^{2}$ was more pronounced than the increase in number of those below such a threshold. Consequently, the period from 1 to $21 \mathrm{~d}$ was characterized by a statistically significant increase of the contribution of the pores with areas ranging from $0.10 \times 10^{-2}$ to $0.55 \times 10^{-2} \mu^{2}$ to porosity, with a simultaneous decrease in the number of pores with areas ranging from $5.5 \times 10^{-2}$ to $10 \times 10^{-2}$ $\mu^{2}$. This realization explains why porosity did not essentially change from 1 to $21 \mathrm{~d}$. Later during ripening, no significant changes $(P<0.05)$ were observed 
in the frequency of pores by area, except that pores with areas below $0.1 \times 10^{-2} \mu \mathrm{m}^{2}$ increased in number, but without any relevant effect upon cheese porosity. Note that in Figure 4B, unlike Figure 4A, the fraction of pores in each class was normalized by the amplitude of said class.

\section{Intrinsic Validity and Variability of Measurements}

The relative contributions of ripening time on the one hand, and of block and section on the other, to the stereological parameters calculated from LM and TEM micrographs are depicted in Figure 5. Analysis

\section{A}
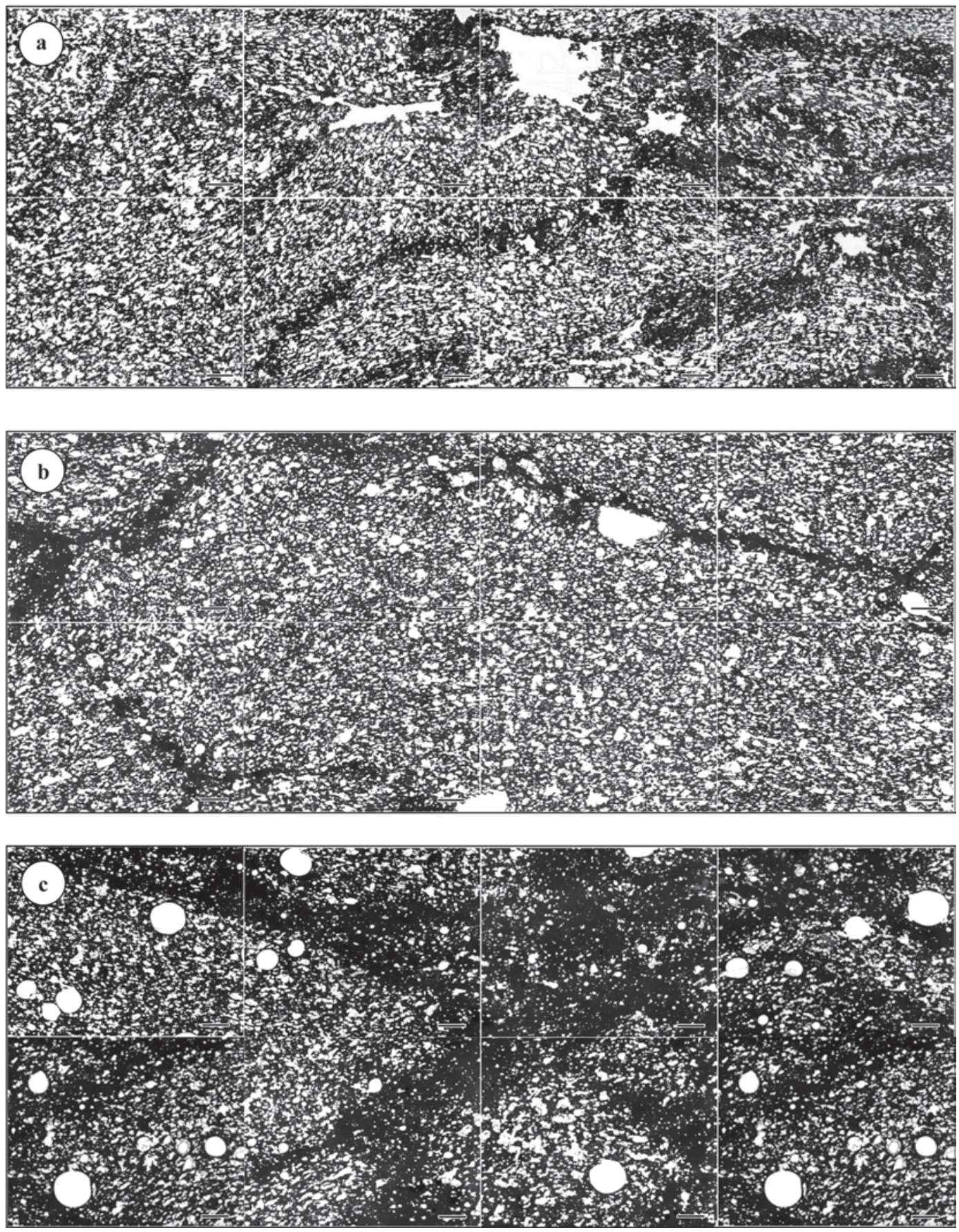

Figure 2. Typical micrographs of cheese samples obtained by light microscopy (A) and transmission electron microscopy (B), by (a) 1 d, (b) $21 \mathrm{~d}$, and (c) $60 \mathrm{~d}$. The bar represents $50 \mu \mathrm{m}$ (A) and $1 \mu \mathrm{m}(\mathrm{B})$. 
B
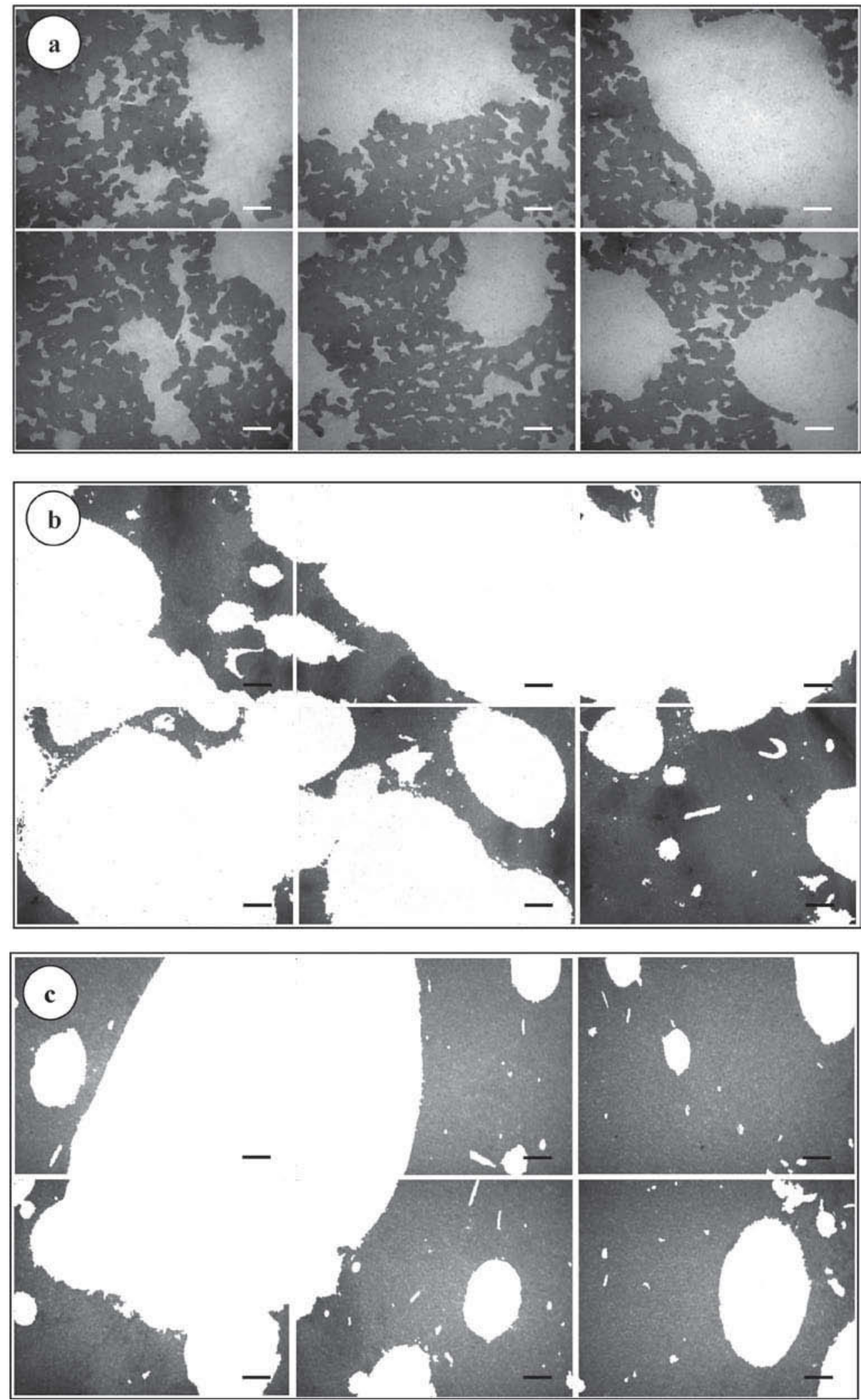

Figure 2 (Continued). Typical micrographs of cheese samples obtained by light microscopy (A) and transmission electron microscopy (B), by (a) $1 \mathrm{~d}$, (b) $21 \mathrm{~d}$, and (c) $60 \mathrm{~d}$. The bar represents $50 \mu \mathrm{m}(\mathrm{A})$ and $1 \mu \mathrm{m}(\mathrm{B})$. 

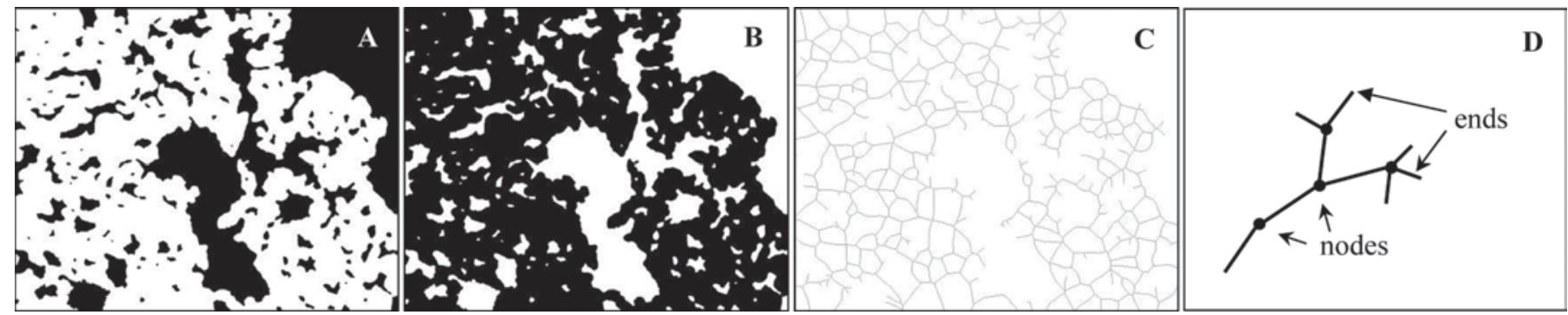

Figure 3. Sequence of imaging procedures encompassing cheese sections: (A) binary image obtained directly, with protein network shown in white and nonprotein phase in black; (B) inverted binary image of A; (C) skeletonized binary image of the protein network of B; and (D) schematic detail of a skeleton in $\mathrm{C}$, with indication of nodes and ends.

of variance revealed that ripening time had a significant effect upon such microstructural parameters as $\mathrm{A}_{\mathrm{A}}, \mathrm{P}_{\mathrm{L}}$, length, nodes, and ends, based on LM images. In the case of $\mathrm{L}_{3}$ and number of pores, ripening time played no significant role; for these parameters, the predominant factors were indeed the fields of view, which accounted for 74.5 and $65.2 \%$, respectively, of the overall variability. A similar trend was observed for the microstructural parameters measured from TEM images, especially $A_{A}$ and $L_{3}$; here, the fields of view accounted for an even higher proportion, namely 94.1 and $98.8 \%$ of the observed variability, respectively. This high relative variability between viewing fields is often found, and tends to increase with the level of magnification; cheese section had a significant $(P<0.05)$ effect toward microstructural parameters measured by LM, but not toward those measured by TEM, and typically followed a Poisson distribution. Although ripening time could explain, to a higher degree, the variation of such TEM-based parameters as $\mathrm{P}_{\mathrm{L}}$, length, ends, and pores, the effect of ripening time was significant $(P<0.05)$ only for the latter (Figure 5). The high heterogeneity detected in Serra da Estrela cheese should, therefore, be emphasized, as it does not occur to such a high level in industrially processed cheeses at large.

With regard to the frequency of pores by area based on TEM images, ANOVA suggests that the viewing fields contributed with most variability, either in terms of number of pores or porosity, whereas the variability between sections explained a large proportion thereof only for those pores in the area range from $0.10 \times 10^{-2}$ to $0.55 \times 10^{-2} \mu^{2}$ (data not shown). On the other hand, the variability accounted for by ripening time was statistically significant only for pores with areas

Table 1. Changes in stereological parameters of cheese throughout ripening time

\begin{tabular}{|c|c|c|c|c|}
\hline \multirow{2}{*}{$\begin{array}{l}\text { Stereological } \\
\text { parameter }^{1}\end{array}$} & \multicolumn{3}{|c|}{ Ripening time $^{2}$} & \multirow{2}{*}{$\begin{array}{c}\text { Time effect } \\
(P \text {-value })\end{array}$} \\
\hline & $1 \mathrm{~d}$ & $21 \mathrm{~d}$ & $60 \mathrm{~d}$ & \\
\hline \multicolumn{5}{|l|}{ LM images ${ }^{3}$} \\
\hline $\mathrm{A}_{\mathrm{A}}(\%)$ & $36.2 \pm 0.5^{\mathrm{a}}$ & $35.3 \pm 0.9^{\mathrm{a}}$ & $30.0 \pm 1.1^{\mathrm{b}}$ & 0.001 \\
\hline $\mathrm{P}_{\mathrm{L}}\left(\mu \mathrm{m}^{-1}\right)$ & $0.406 \pm 0.007^{\mathrm{a}}$ & $0.370 \pm 0.010^{\mathrm{b}}$ & $0.329 \pm 0.009^{c}$ & 0.007 \\
\hline $\mathrm{L}_{3}(\mu \mathrm{m})$ & $2.70 \pm 0.04^{\mathrm{a}}$ & $2.90 \pm 0.06^{\mathrm{a}}$ & $2.74 \pm 0.05^{\mathrm{a}}$ & 0.164 \\
\hline Length $\left(\mu \mathrm{m}^{-1}\right)$ & $0.103 \pm 0.002^{\mathrm{a}}$ & $0.076 \pm 0.003^{\mathrm{b}}$ & $0.066 \pm 0.004^{\mathrm{b}}$ & 0.000 \\
\hline Nodes $\left(\times 10^{-3} \mu \mathrm{m}^{-2}\right)$ & $9.6 \pm 0.4^{\mathrm{a}}$ & $6.4 \pm 0.4^{\mathrm{b}}$ & $5.9 \pm 0.5^{\mathrm{b}}$ & 0.000 \\
\hline Ends $\left(\times 10^{-3} \mu \mathrm{m}^{-2}\right)$ & $27.8 \pm 0.3^{\mathrm{a}}$ & $24.3 \pm 0.9^{\mathrm{b}}$ & $23.3 \pm 0.5^{\mathrm{b}}$ & 0.006 \\
\hline Pores $\left(\times 10^{-3} \mu \mathrm{m}^{-2}\right)$ & $10.7 \pm 0.1^{\mathrm{a}}$ & $10.6 \pm 0.5^{\mathrm{a}}$ & $10.7 \pm 0.2^{\mathrm{a}}$ & 0.930 \\
\hline \multicolumn{5}{|l|}{ TEM images $^{4}$} \\
\hline $\mathrm{A}_{\mathrm{A}}(\%)$ & $6.5 \pm 0.9^{\mathrm{a}}$ & $3.4 \pm 1.3^{\mathrm{a}}$ & $4.7 \pm 0.4^{\mathrm{a}}$ & 0.331 \\
\hline $\mathrm{P}_{\mathrm{L}}\left(\mu \mathrm{m}^{-1}\right)$ & $79.0 \pm 10.5^{\mathrm{a}}$ & $26.2 \pm 3.5^{\mathrm{b}}$ & $32.2 \pm 4.8^{\mathrm{b}}$ & 0.055 \\
\hline $\mathrm{L}_{3}(\mu \mathrm{m})$ & $0.096 \pm 0.006^{\mathrm{a}}$ & $0.118 \pm 0.025^{\mathrm{ab}}$ & $0.169 \pm 0.019^{\mathrm{b}}$ & 0.220 \\
\hline Length $\left(\mu \mathrm{m}^{-1}\right)$ & $0.42 \pm 0.06^{\mathrm{a}}$ & $0.14 \pm 0.03^{\mathrm{b}}$ & $0.21 \pm 0.02^{\mathrm{b}}$ & 0.080 \\
\hline Nodes $\left(\times 10^{-3} \mu \mathrm{m}^{-2}\right)$ & $792 \pm 119^{\mathrm{a}}$ & $271 \pm 47^{\mathrm{b}}$ & $463 \pm 102^{\mathrm{b}}$ & 0.170 \\
\hline Ends $\left(\times 10^{-3} \mu \mathrm{m}^{-2}\right)$ & $2,698 \pm 299^{\mathrm{a}}$ & $1,081 \pm 148^{\mathrm{b}}$ & $1,404 \pm 267^{\mathrm{b}}$ & 0.068 \\
\hline Pores $\left(\times 10^{-3} \mu \mathrm{m}^{-2}\right)$ & $972 \pm 99^{\mathrm{a}}$ & $415 \pm 52^{\mathrm{b}}$ & $483 \pm 88^{\mathrm{b}}$ & 0.040 \\
\hline
\end{tabular}

${ }^{\mathrm{a}-\mathrm{c}}$ Means within a row, not followed by the same superscript, are statistically different $(P<0.05)$.

${ }^{1} \mathrm{LM}=$ light microscopy; TEM = transmission electron microscopy; $\mathrm{A}_{\mathrm{A}}=$ area fraction of the nonprotein phase;

$\mathrm{P}_{\mathrm{L}}=$ half of surface/volume ratio; $\mathrm{L}_{3}=$ mean intercept length.

${ }^{2}$ Values are expressed as mean \pm SEM.

${ }^{3}$ Four true replicates $\times 9$ analytical replicates.

${ }^{4}$ Four true replicates $\times 6$ analytical replicates. 


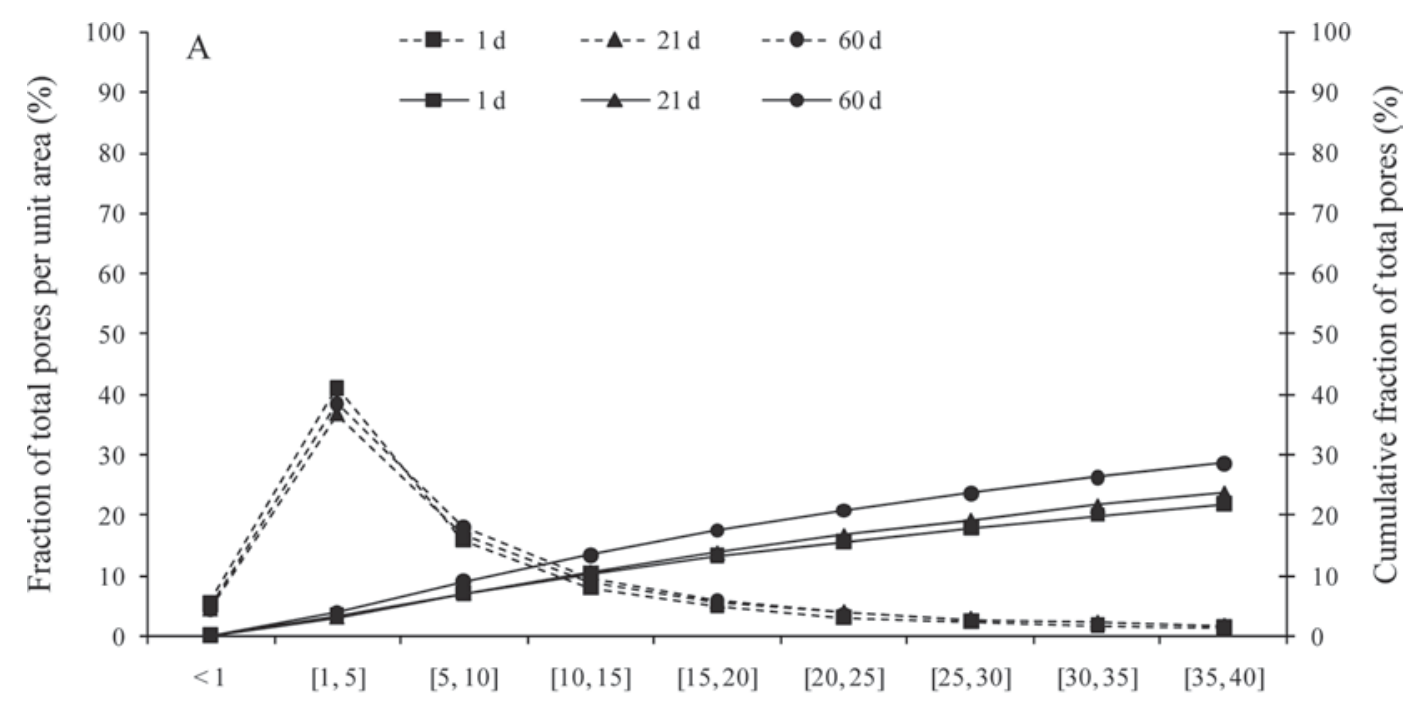

Pore area $\left(\mu \mathrm{m}^{2}\right)$

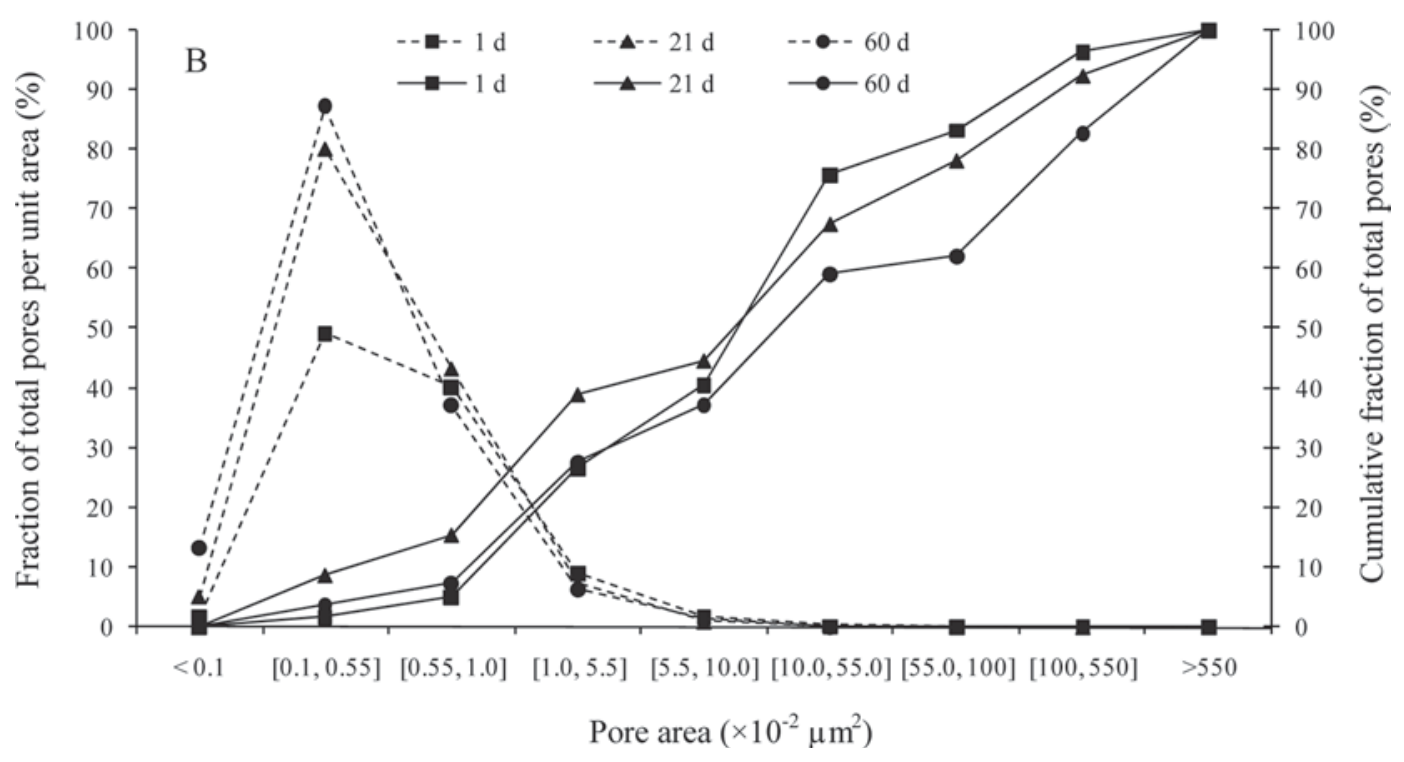

Figure 4. Fractional distribution of pores per area classes, as obtained by light microscopy (A) and transmission electron microscopy (B), throughout ripening time, in absolute (symbols with dashed line, left axis) and cumulative terms (symbols with solid line, right axis).

from $0.10 \times 10^{-2}$ to $0.55 \times 10^{-2}$, and from $55 \times 10^{-2}$ to $100 \times 10^{-2} \mu \mathrm{m}^{2}$ (33.1 and $11.0 \%$, respectively). When porosity was considered, the variability accounted for by ripening time was significant $(P<0.05)$ only for pores with individual areas below $0.1 \times 10^{-2} \mu \mathrm{m}^{2}$. If LM images were considered instead, ripening time and cheese section had a significant effect upon the pore distribution for pores in the ranges from 25 to 30 and from 35 to $40 \mu^{2}$, and likewise in terms of porosity, ex- cept for pores in the range of 5 to $10 \mu \mathrm{m}^{2}$. As expected, cheese block had no significant effect $(P>0.05)$ upon any of the structural parameters studied, so random sampling appeared to be effective.

When performing the textural assays, it might be argued that the $2-\mathrm{mm}$ probe used was too thin to cause significant compression of the sample; however, Breuil and Meullenet (2001) found a significant correlation between measurements using a similar probe and textural 


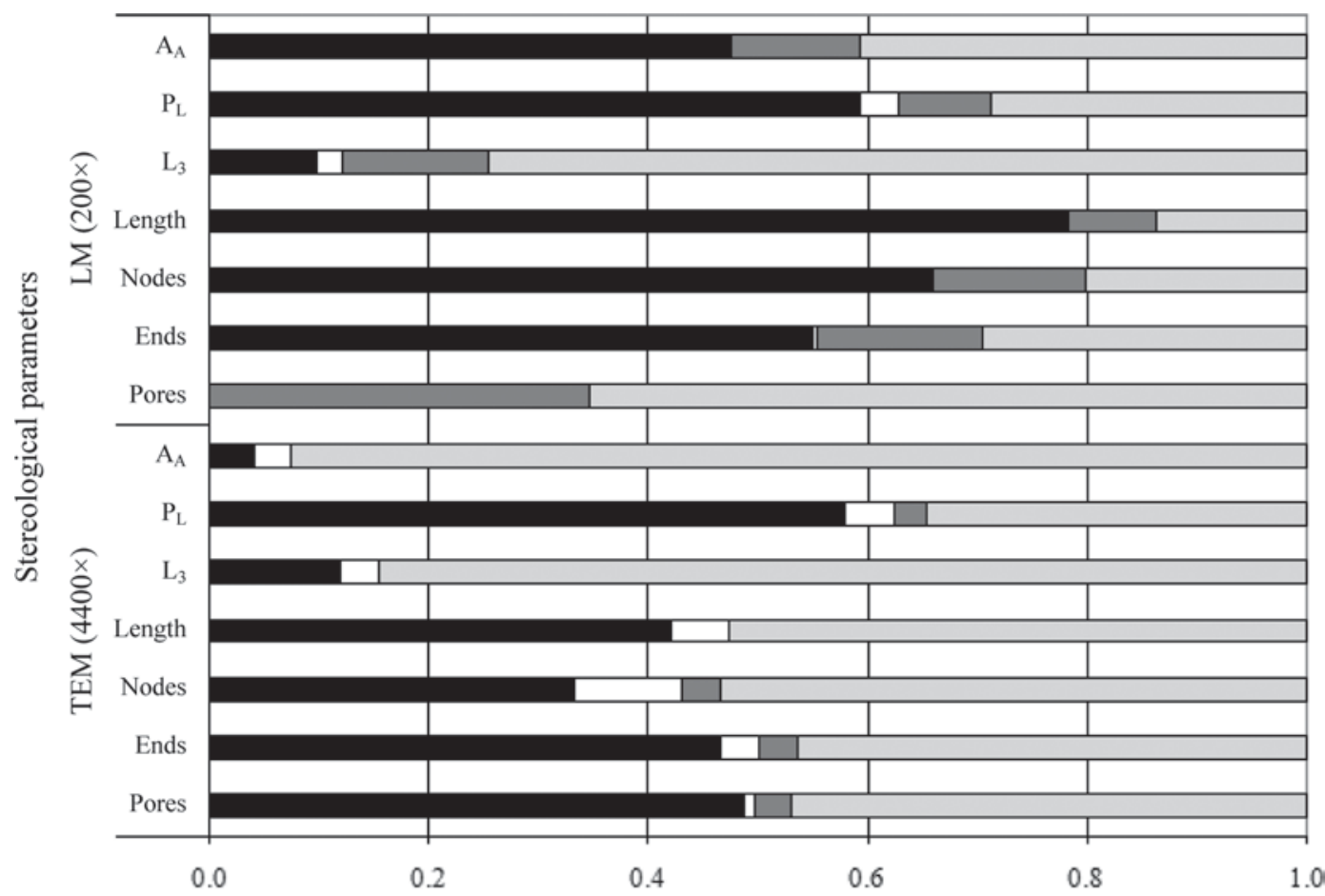

Fraction of total variance

Figure 5. Contributions of ripening time (black), block (white), and section factors (dark gray), and of intrinsic replicate variabilities (light gray) to the total variance of stereological data. TEM $=$ transmission electron microscopy; $\mathrm{LM}=$ light microscopy; $\mathrm{A}_{\mathrm{A}}=$ area fraction of the nonprotein phase; $\mathrm{P}_{\mathrm{L}}=$ half of surface/volume ratio; $\mathrm{L}_{3}=$ mean intercept length.

characteristics of a wide range of commercial cheeses (also validated by a sensory panel), so this approach was elected here.

Relating to microscopic observations, formalin has the advantage of penetrating quickly (within a matter of minutes) the cheese sample, owing to the porosity of the latter and the small molecular size of the former, so ripening vectors were readily inactivated; however, complete structural stabilization of the samples took longer, because crosslinking with molecules is a relatively slow process. In any case, the aforementioned fixative disables enzymes (e.g., proteases) fast that would otherwise change the sample, and its toxicity to most microorganisms precludes further metabolic changes in the sample as well. On the other hand, LM should preferably be used on native cheese samples; however, the unique composition of this cheese led to poor micrographs, and confocal microscopy produced observations excessively blurred to be useful; therefore, only fixed samples were exposed to LM (which would anyway be strictly required, to obtain valid quantitative information by stereological techniques).

Finally, each stereological parameter was estimated from 72 and 36 fields of view per cheese, for LM and TEM, respectively. Despite the large percent of variabil- ity among fields of view, their number could not grow without limit, so a balance between limited analytical resources and intrinsic heterogeneity of the samples was eventually attained.

\section{Relationships Between Microstructural Parameters}

In attempts to unfold interrelationships among stereological parameters, while simultaneously detecting the most important causes of variability, PCA was applied. First, the Kaiser-Meyer-Olkin measure (KMO) and the Bartlett test of sphericity indicated that the environment data were suitable for that analysis $(\mathrm{KMO}=0.682$ and $\chi^{2}=3938.885$, respectively, with $P<0.01$ ). Four principal components could, thus, be extracted, which accounted for $90.8 \%$ of the whole variability within the original data set (see Table 2); commonalities involving the variables selected were high, so they also shared a considerable variance.

Based on the rotation sum of squares loadings, the first principal component accounted for $45.1 \%$ of the total variance; variables that loaded higher onto this component reflected mainly the microstructural characteristics assessed by TEM, except $\mathrm{A}_{\mathrm{A}}$ and $\mathrm{L}_{3}$. The second principal component accounted for $22.5 \%$ of the 
Table 2. Significant $(P<0.01)$ correlations between stereological parameters, expressed as principal components $^{1}$

\begin{tabular}{|c|c|c|c|c|c|}
\hline \multirow[b]{2}{*}{ Item $^{2}$} & \multicolumn{4}{|c|}{ Principal component } & \multirow[b]{2}{*}{ Commonalities } \\
\hline & 1 & 2 & 3 & 4 & \\
\hline \multicolumn{6}{|l|}{ LM images } \\
\hline $\mathrm{A}_{\mathrm{A}}(\%)$ & & 0.872 & -0.328 & & 0.887 \\
\hline $\mathrm{P}_{\mathrm{L}}\left(\mu \mathrm{m}^{-1}\right)$ & & 0.804 & 0.440 & & 0.887 \\
\hline $\mathrm{L}_{3}(\mu \mathrm{m})$ & & & -0.833 & & 0.827 \\
\hline Length $\left(\mu \mathrm{m}^{-1}\right)$ & & 0.910 & & & 0.909 \\
\hline Nodes $\left(\times 10^{-3} \mu \mathrm{m}^{-2}\right)$ & 0.320 & 0.815 & & & 0.775 \\
\hline $\operatorname{Ends}^{3}\left(\times 10^{-3} \mu \mathrm{m}^{-2}\right)$ & & 0.596 & 0.731 & & 0.945 \\
\hline Pores $\left(\times 10^{-3} \mu \mathrm{m}^{-2}\right)$ & & & 0.914 & & 0.848 \\
\hline \multicolumn{6}{|l|}{ TEM images } \\
\hline $\mathrm{A}_{\mathrm{A}}(\%)$ & 0.470 & & & 0.852 & 0.948 \\
\hline $\mathrm{P}_{\mathrm{L}}\left(\mu \mathrm{m}^{-1}\right)$ & 0.909 & & & & 0.959 \\
\hline $\mathrm{L}_{3}(\mu \mathrm{m})$ & & & & 0.936 & 0.934 \\
\hline Length $\left(\mu \mathrm{m}^{-1}\right)$ & 0.800 & & & 0.530 & 0.966 \\
\hline Nodes $\left(\times 10^{-3} \mu \mathrm{m}^{-2}\right)$ & 0.917 & & & & 0.928 \\
\hline Ends $\left(\times 10^{-3} \mu \mathrm{m}^{-2}\right)$ & 0.967 & & & & 0.975 \\
\hline Pores $\left(\times 10^{-3} \mu \mathrm{m}^{-2}\right)$ & 0.939 & & & & 0.930 \\
\hline \multicolumn{6}{|l|}{ Variability } \\
\hline Initial eigenvalues & 6.3130 & 3.1440 & 2.036 & 1.225 & \\
\hline Variance explained (\%) & 45.093 & 22.457 & 14.544 & 8.751 & \\
\hline Cumulative variance explained (\%) & 45.093 & 67.550 & 82.094 & 90.845 & \\
\hline
\end{tabular}

total variance and was defined by almost all LM variables, except $\mathrm{L}_{3}$, ends, and number of pores. The third principal component accounted for $14.5 \%$ of the total variance; it was related to such LM characteristics as $\mathrm{L}_{3}$, ends, and number of pores. Finally, the fourth principal component was dominated by $\mathrm{A}_{\mathrm{A}}$ and $\mathrm{L}_{3}$, both determined by TEM, and accounted for $8.8 \%$ of the total variance. A deeper analysis of the first principal component indicates that almost all variables measured by TEM are highly correlated with each other ( $\mathrm{r}>$ $0.8, P<0.01$ ), whereas the variables with high factor loadings on the second principal component are more related to cheese microstructure as dictated by LM observations.

In order to more easily ascertain the influence of ripening time, the scores of cheese samples by 1, 21, and $60 \mathrm{~d}$, as well as the relevant processing variables were displayed on the same 2D plot (Figure 6); each variable is represented by a line starting at the origin of the plot, and ending at a point with coordinates given by the loadings on the 2 dimensions. Note that the TEM variables appear close to each other (at the bottom right corner of Figure 6), thus indicating a strong relationship between them (i.e., the smaller the angle between the associated vectors, the higher the correlation between the corresponding variables). A similar rationale applied to the 4 lines depicting variables $\mathrm{A}_{\mathrm{A}}$, $\mathrm{P}_{\mathrm{L}}$, length, and nodes (at the upper right corner): al- though all retained variables exhibited high (positive) loadings along dimension 1, dimension 2 could discriminate the 4 variables based on LM from the 5 variables based on TEM: variables associated with LM loaded positively along dimension 2 , whereas those associated with TEM did so negatively. This indicates that cheese samples with high values on dimension 1 will report relatively high values on both LM and TEM vectors, and vice-versa; cheese samples with high positive, or negative values on dimension 2 will be more, or less, oriented toward LM than TEM vectors, respectively. Because categorical PCA was able to explain $85.6 \%$ of the total variance via its first 2 factors, the associated dimensionality of the results could be reduced to 2 components at the expense of only $14.4 \%$ loss in variance, which is an interesting and useful practical result. Furthermore, Figure 6 suggests that microstructural parameters are closely related with ripening time; on average, 21- and 60-d cheeses scored similarly on dimension 1 , but yielded opposite values on dimension 2 , although they partially overlapped on this dimension; their values on dimension 1 differed significantly from those by $1 \mathrm{~d}$.

One observes that 1-d cheeses were spread over 2 quadrants that are formed by the positive part of the LM lines and the positive part of the TEM lines; 21-d cheese samples tended to lie on the negative side of TEM vectors, thus implying that nanostructure plays 
a less important role; and 60-d cheeses lay chiefly on the quadrant formed by the negative side of the lines representing LM, so microstructural differences were also important at later stages of ripening. In other words, cheeses by $1 \mathrm{~d}$ are characterized by relatively high values on the scales that represent both dimensions, whereas $21 \mathrm{~d}$-old cheeses lead to low values on the scales representing TEM and LM (except $\mathrm{A}_{\mathrm{A}}$ ), and $60 \mathrm{~d}$-old cheeses are characterized by low values on the scales representative of both dimensions. The plot of component loadings (Figure 6) also outlined the fact that $\mathrm{A}_{\mathrm{A}}$ can be considered as being independent from any TEM-associated parameters because the latter lines are more or less perpendicular to the $\mathrm{A}_{\mathrm{A}}$ line.

\section{Relationships Between Microstructural, Chemical, and Rheological Parameters}

No significant changes were observed in fat, $\mathrm{NaCl}$, and protein contents (which yielded $49.8 \%, 3.4 \%$, and $41.6 \%$ on average, respectively, on a dry matter basis) along ripening. The initial $\mathrm{pH}$ of cheese was ca. 5.8, but decreased significantly thereafter until $21 \mathrm{~d}$, remaining at ca. 4.9 throughout the remainder of ripening. The titratable acidity also decreased significantly throughout the $60-\mathrm{d}$ period. No significant changes were perceived in moisture content during the first $21 \mathrm{~d}$ of ripening, unlike between 21 and $60 \mathrm{~d}$ (with significant decreases from 54.0 to $46.9 \%$, between 21 and $60 \mathrm{~d}$ of ripening, as mentioned before). The concentrations of WSN, TCASN, and PTASN, expressed as percentage of total nitrogen, increased significantly during ripening: from 9.62 to $23.33 \%$, from 1.48 to $3.71 \%$, and from 0.56 to $2.60 \%$, respectively, between 1 and $60 \mathrm{~d}$.

Pearson correlation coefficients were calculated to back up any suspected linear relationships between microstructural parameters (based on LM and TEM images) and nitrogen fractions (i.e., WSN, TCASN, and PTASN) throughout ripening time. The corresponding results, listed in Table 3, show that all microstructural parameters bore a negative correlation with nitrogen fractions, except $\mathrm{L}_{3}$, which held a positive correlation; however, it was significant $(P<0.05)$ only for those pores measured by TEM. Hence, it seems that $\mathrm{L}_{3}$ increases as proteolysis takes place. Apart from $\mathrm{L}_{3}$ and number of pores, all LM-based parameters entertained a significant correlation $(P<0.01)$ with the aforementioned nitrogen fractions. In general, said parameters were better correlated with the nitrogen fractions (with absolute correlation coefficients ranging between 0.6 and 0.9) than were TEM-based ones (with absolute correlation coefficients ranging merely from 0.4 to 0.7 ), hence suggesting that structure revealed by LM (i.e.,

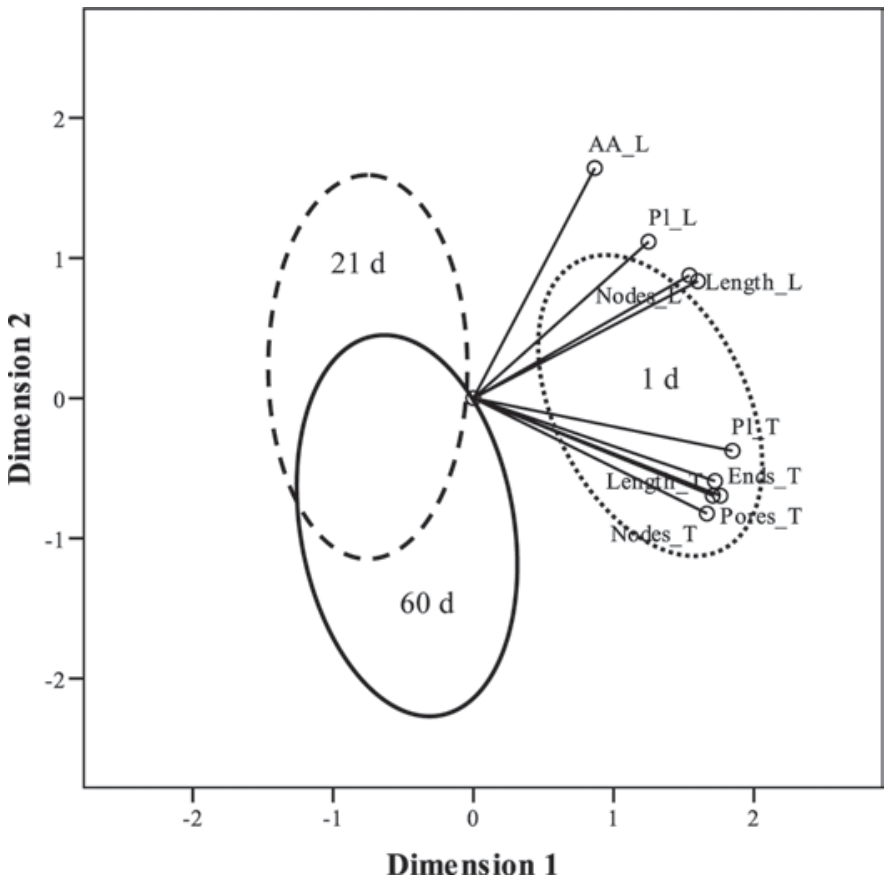

Figure 6. Loading score plot in terms of the first 2 principal components $(\mathrm{n}=108)$, pertaining to light microscopy $\left(\_L\right)$ and transmission electron microscopy (_T), throughout ripening time $(1,21$, and $60 \mathrm{~d}$ ), and encompassing such stereological parameters as area fraction of the nonprotein phase (AA), half of the surface/volume ratio (Pl), length, nodes, ends, and pores.

microstructure) could more clearly reflect cheese aging than that revealed by TEM (i.e., nanostructure).

The most important biochemical reactions occurring in most varieties of cheese during ripening are related to proteolysis (Fox and McSweeney, 1996); primary proteolysis (measured chiefly by WSN) causes softening of the cheese matrix early during ripening, via disruption of its 3-dimensional protein network (Fox et al., 1993), whereas secondary proteolysis, brought about by the microflora rather than the residual rennet (and measured chiefly by PTASN), causes a more localized breakdown. This is somewhat consistent with the good correlations found between $\mathrm{A}_{\mathrm{A}}$ (measured by LM) and PTASN $(\mathrm{r}=-0.798, P<0.01)$, and to a slightly lesser extent with TCASN $(\mathrm{r}=-0.717, P<0.01)$ and WSN $(\mathrm{r}=-0.670, P<0.01)$; hence, it appears that ripening depth reflected changes in $\mathrm{A}_{\mathrm{A}}$. The highest correlation coefficients were found between length (measured by $\mathrm{LM})$ and WSN $(\mathrm{r}=-0.890, P<0.01)$; length was also well correlated with PTASN $(\mathrm{r}=-0.777, P<0.01)$ and TCASN ( $\mathrm{r}=-0.772, P<0.01)$, but to lesser degrees. Likewise, $\mathrm{P}_{\mathrm{L}}$ (as measured by LM) did correlate well with WSN $(\mathrm{r}=-0.787, P<0.01)$, PTASN $(\mathrm{r}=-0.788$, $P<0.01)$, and TCASN $(\mathrm{r}=-0.755, P<0.01)$. There- 
Table 3. Significant correlations between stereological parameters and cheese ripening parameters

\begin{tabular}{|c|c|c|c|}
\hline \multirow[b]{2}{*}{$\begin{array}{l}\text { Stereological } \\
\text { parameter }^{1}\end{array}$} & \multicolumn{3}{|c|}{ Ripening parameter $^{2}$} \\
\hline & $\begin{array}{c}\text { WSN } \\
(\%, w t / w t)\end{array}$ & $\begin{array}{c}\text { TCASN } \\
(\%, \mathrm{wt} / \mathrm{wt})\end{array}$ & $\begin{array}{c}\text { PTASN } \\
(\%, \text { wt } / w t)\end{array}$ \\
\hline \multicolumn{4}{|l|}{ LM $_{\text {images }}{ }^{3}$} \\
\hline $\mathrm{A}_{\mathrm{A}}(\%)$ & $-0.670^{* *}$ & $-0.717^{* *}$ & $-0.798^{* *}$ \\
\hline $\mathrm{P}_{\mathrm{L}}\left(\mu \mathrm{m}^{-1}\right)$ & $-0.787^{* *}$ & $-0.755^{* *}$ & $-0.788^{* *}$ \\
\hline $\mathrm{L}_{3}(\mu \mathrm{m})$ & & & \\
\hline Length $\left(\mu \mathrm{m}^{-1}\right)$ & $-0.890^{* *}$ & $-0.772^{* *}$ & $-0.777^{* *}$ \\
\hline Nodes $\left(\times 10^{-3} \mu \mathrm{m}^{-2}\right)$ & $-0.780 * *$ & $-0.655^{* *}$ & $-0.645^{* *}$ \\
\hline Ends $\left(\times 10^{-3} \mu \mathrm{m}^{-2}\right)$ & $-0.755^{* *}$ & $-0.623^{* *}$ & $-0.625^{* *}$ \\
\hline Pores $\left(\times 10^{-3} \mu \mathrm{m}^{-2}\right)$ & & & \\
\hline \multicolumn{4}{|l|}{ TEM images ${ }^{4}$} \\
\hline \multicolumn{4}{|l|}{$\mathrm{A}_{\mathrm{A}}(\%)$} \\
\hline $\mathrm{P}_{\mathrm{L}}\left(\mu \mathrm{m}^{-1}\right)$ & $-0.716^{* *}$ & $-0.562^{* *}$ & $-0.452^{*}$ \\
\hline $\mathrm{L}_{3}(\mu \mathrm{m})$ & $0.536^{*}$ & $0.596^{* *}$ & $0.570^{* *}$ \\
\hline Length $\left(\mu \mathrm{m}^{-1}\right)$ & $-0.630^{* *}$ & $-0.437^{*}$ & \\
\hline Nodes $\left(\times 10^{-3} \mu \mathrm{m}^{-2}\right)$ & $-0.488^{*}$ & & \\
\hline Ends $\left(\times 10^{-3} \mu \mathrm{m}^{-2}\right)$ & $-0.628^{* *}$ & $-0.483^{*}$ & \\
\hline Pores $\left(\times 10^{-3} \mu \mathrm{m}^{-2}\right)$ & $-0.675^{* *}$ & $-0.548^{* *}$ & $-0.413^{*}$ \\
\hline
\end{tabular}

${ }^{1} \mathrm{LM}=$ light microscopy; TEM = transmission electron microscopy; $\mathrm{A}_{\mathrm{A}}=$ area fraction of the nonprotein phase; $\mathrm{P}_{\mathrm{L}}=$ half of surface/volume ratio; $\mathrm{L}_{3}=$ mean intercept length.

${ }^{2} \mathrm{WSN}=$ water-soluble nitrogen; TCASN $=$ trichloroacetic acid-soluble nitrogen; PTASN $=$ phosphotungstic acid-soluble nitrogen.

${ }^{3}$ Twelve true replicates $\times 9$ analytical replicates.

${ }^{4}$ Twelve true replicates $\times 6$ analytical replicates.

${ }^{*} P<0.05 ;{ }^{*} P<0.01$ : significant correlation (single-tailed).

fore, as proteolysis occurs, length, $\mathrm{P}_{\mathrm{L}}$ and $\mathrm{A}_{\mathrm{A}}$ decrease, and thus reflect a coarser protein network.

Considering TEM-based parameters, the highest correlations were found between $\mathrm{P}_{\mathrm{L}}$ and WSN $(\mathrm{r}=-0.716$, $P<0.01)$ and TCASN $(\mathrm{r}=-0.562, P<0.01)$. The area occupied by pores exhibited no significant correlations with the aforementioned nitrogen fractions; this realization is consistent with the data tabulated in Table 1. The $\mathrm{L}_{3}$ was poorly correlated with WSN $(\mathrm{r}=0.536, P$ $<0.05)$, TCASN $(\mathrm{r}=0.596, P<0.01)$, and PTASN $(\mathrm{r}$ $=0.570, P<0.01)$. From TEM images, it seemed that the volume of individual pores increased as ripening time elapsed; however, the variability among fields of view accounted for more than $80 \%$ (Figure 5).

Correlation coefficients were likewise calculated as a means to ascertain putative relationships between microstructural and rheological parameters (Table 4). As expected, $A_{A}$ was negatively correlated $(P<$ 0.01) with fracturability, firmness, gumminess, chewiness, and Young's modulus (with absolute correlation coefficients above $0.7, P<0.01$ ). It is well known that increasing the moisture content or the ratio of moisture to protein weakens the cheese continuum, because the volumetric fraction of protein (i.e., the backbone of the curd) decreases. On the other hand, the adhesiveness yielded a positive correlation with $\mathrm{A}_{\mathrm{A}}(\mathrm{r}=0.757, P$ $<0.01$ ); recall that adhesiveness in Serra da Estrela cheese remained essentially constant up to $21 \mathrm{~d}$, but decreased significantly by $60 \mathrm{~d}$. Similar correlations were observed between $\mathrm{P}_{\mathrm{L}}$ and the foregoing rheological parameters. In particular, it is interesting to note that $\mathrm{L}_{3}$ (measured by LM) entertained a significantly better correlation with springiness $(\mathrm{r}=-0.498, P<0.01)$; it seems that $\mathrm{L}_{3}$ may be directly related to weakening of the proteinaceous network.

As happened with the nitrogen fractions, LM parameters, in general, correlated better with rheological parameters than did TEM-based ones. Surprisingly, springiness exhibited a stronger correlation with TEMthan LM-based parameters, in particular with $\mathrm{P}_{\mathrm{L}}(\mathrm{r}$ $=0.769, P<0.01)$ and length $(\mathrm{r}=0.767, P<0.01)$. Finally, length correlated better with rheological parameters, mainly fracturability.

In view of the above, changes in the extent of proteolysis can apparently be predicted via microstructural parameters (and vice-versa), especially in the case of TCASN and PTASN. Furthermore, several rheological features of cheese, in particular fracturability, adhesiveness, and Young's modulus, can also be accurately predicted by microstructural parameters (and vice versa).

The underlying hypothesis of this study was that changes in cheese microstructure are associated with changes in chemical parameters throughout ripening. Multiple regression analysis was, thus, carried out, encompassing microstructural parameters and proteolytic indices. The results are listed in Table 5, and indicate 
Table 4. Significant correlations between stereological parameters and texture parameters

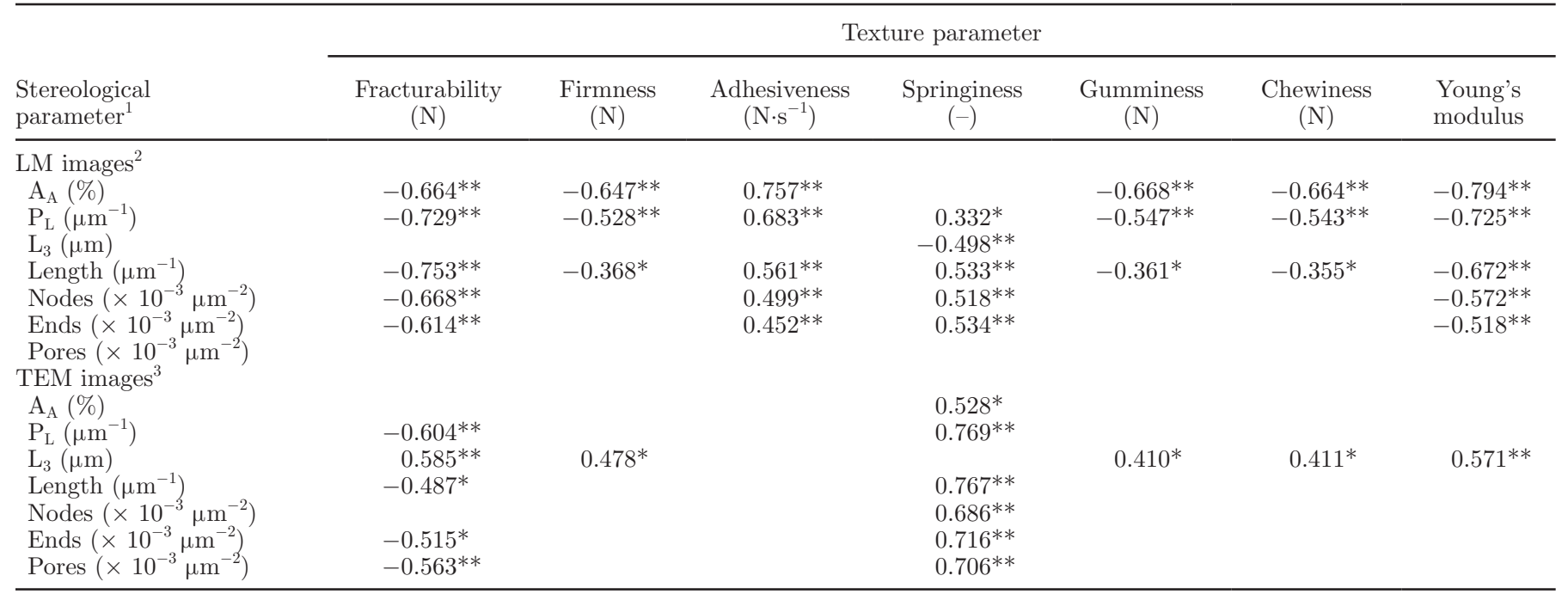

${ }^{1} \mathrm{LM}=$ light microscopy; TEM $=$ transmission electron microscopy; $\mathrm{A}_{\mathrm{A}}=$ area fraction of the nonprotein phase; $\mathrm{P}_{\mathrm{L}}=$ half of surface/volume ratio; $\mathrm{L}_{3}=$ mean intercept length.

${ }^{2}$ Twelve true replicates $\times 9$ analytical replicates.

${ }^{3}$ Twelve true replicates $\times 6$ analytical replicates.

${ }^{*} P<0.05 ;{ }^{* *} P<0.01$ : significant correlation (single-tailed).

that the proportion of variance explained by LM- and TEM-based parameters considered together was similar to that explained by LM- or TEM-based parameters considered independently. However, by leaving LM- or TEM-based parameters out of the regression analysis, the adjusted coefficient of determination was not greatly reduced, so LM- and TEM-based parameters entertain similar importance with regard to nitrogen fractions (WSN, TCASN, and PTASN). Surprisingly, when the parameters estimated from TEM images were considered, a slight improvement resulted relative to using only LM-based parameters in attempts to predict the aforementioned proteolytic indices.

All models used to predict WSN, TCASN, and PTASN were highly significant $(P<0.0001$; Table $6)$. The regression coefficients associated with the standardized variables implied that $\mathrm{P}_{\mathrm{L}}$ and number of pores, estimated from LM images, as well as $\mathrm{A}_{\mathrm{A}}, \mathrm{L}_{3}$, and nodes, estimated from TEM images, were significant in the models encompassing WSN, TCASN, and PTASN. This result was not at all unexpected, because $\mathrm{P}_{\mathrm{L}}$ measured by LM correlated well with the nitrogen fractions; however, $\mathrm{L}_{3}$ and nodes from TEM, which are poorly related to each other $(|\mathrm{r}| \leq 0.6)$, and pores from LM images and $\mathrm{A}_{\mathrm{A}}$ from TEM images, which bear no significant correlations with any nitrogen fraction, were considered significant in terms of the regression models (Table 6). As happened with the correlation coefficients, length from TEM was significant in efforts to predict WSN $(P<0.01)$ and TCASN $(P<0.05)$; when said length increased, WSN and TCASN decreased, whereas when $\mathrm{P}_{\mathrm{L}}$ from TEM increased, all of those proteolytic indices decreased. Therefore, such LM-based parameters as $\mathrm{A}_{\mathrm{A}}, \mathrm{P}_{\mathrm{L}}$, length, nodes, and ends appear to be good candidates to relate the extent of proteolysis and the rheological parameters to the microstructural properties of Serra da Estrela cheese.

\section{CONCLUSIONS}

Stereological image analysis was found useful in discriminating among cheeses ripened for different periods. By combining microstructural data with chemical and textural ones, LM-based parameters appeared, in

Table 5. Adjusted coefficient of determination ( \pm SE of the estimate) for linear regression equations between stereological parameters and ripening parameters

\begin{tabular}{lccc}
\hline & \multicolumn{3}{c}{ Ripening parameter $^{2}$} \\
\cline { 2 - 4 } $\begin{array}{l}\text { Stereological } \\
\text { parameter }\end{array}$ & $\begin{array}{c}\text { WSN }^{3} \\
(\%, \mathrm{wt} / \mathrm{wt})\end{array}$ & $\begin{array}{c}\text { TCASN }^{3} \\
(\%, \mathrm{wt} / \mathrm{wt})\end{array}$ & $\begin{array}{c}\text { PTASN }^{4} \\
(\%, \mathrm{wt} / \mathrm{wt})\end{array}$ \\
\hline LM & $0.815 \pm 0.436$ & $0.621 \pm 0.611$ & $0.651 \pm 0.604$ \\
TEM & $0.838 \pm 0.420$ & $0.858 \pm 0.370$ & $0.761 \pm 0.523$ \\
LM + TEM & $0.981 \pm 0.143$ & $0.960 \pm 0.197$ & $0.973 \pm 0.177$ \\
\hline
\end{tabular}

${ }^{1} \mathrm{LM}=$ light microscopy; TEM $=$ transmission electron microscopy.

${ }^{2} \mathrm{WSN}=$ water-soluble nitrogen; TCASN $=$ trichloroacetic acid-soluble nitrogen; PTASN = phosphotungstic acid-soluble nitrogen.

${ }^{3}$ Twelve true replicates $\times 6$ analytical replicates.

${ }^{4}$ Twelve true replicates $\times 9$ analytical replicates. 
Table 6. Linear regression equations (expressed as partial regression coefficients) between stereological parameters and ripening parameters

\begin{tabular}{|c|c|c|c|}
\hline \multirow[b]{2}{*}{ Item $^{1}$} & \multicolumn{3}{|c|}{ Ripening parameter ${ }^{2}$} \\
\hline & $\begin{array}{c}\mathrm{WSN}^{3} \\
(\%, \mathrm{wt} / \mathrm{wt})\end{array}$ & $\begin{array}{c}\mathrm{TCASN}^{3} \\
(\%, \mathrm{wt} / \mathrm{wt})\end{array}$ & $\begin{array}{l}\text { PTASN }^{4} \\
(\%, \mathrm{wt} / \mathrm{wt})\end{array}$ \\
\hline Intercept & $27.099^{* * *}$ & $4.469^{* * *}$ & $43.319^{*}$ \\
\hline \multicolumn{4}{|l|}{ LM images } \\
\hline $\mathrm{A}_{\mathrm{A}}(\%)$ & $0.858^{* *}$ & & \\
\hline $\mathrm{P}_{\mathrm{L}}\left(\mu \mathrm{m}^{-1}\right)$ & $-121.679^{* * *}$ & $-17.250^{* * *}$ & $-133.571^{*}$ \\
\hline $\mathrm{L}_{3}(\mu \mathrm{m})$ & & & $-13.918^{*}$ \\
\hline Length $\left(\mu \mathrm{m}^{-1}\right)$ & $-391.102^{* * *}$ & $38.991^{*}$ & \\
\hline Nodes $\left(\times 10^{-3} \mu \mathrm{m}^{-2}\right)$ & $1,740.875^{* * *}$ & & $429.626^{* *}$ \\
\hline Ends $\left(\times 10^{-3} \mu \mathrm{m}^{-2}\right)$ & & & $-294.842^{* *}$ \\
\hline Pores $\left(\times 10^{-3} \mu \mathrm{m}^{-2}\right)$ & $1,714.354^{* * *}$ & $642.981^{* *}$ & $960.611^{* *}$ \\
\hline \multicolumn{4}{|l|}{ TEM images } \\
\hline $\begin{array}{l}\mathrm{A}_{\mathrm{A}}(\%) \\
\mathrm{P}_{\mathrm{L}}\left(\mu \mathrm{m}^{-1}\right)\end{array}$ & $-2.089^{* * *}$ & $-0.592^{* * *}$ & $-0.464^{* * *}$ \\
\hline $\mathrm{L}_{3}(\mu \mathrm{m})$ & $83.037^{* * *}$ & $20.217^{* * *}$ & $14.750^{* *}$ \\
\hline Length $\left(\mu \mathrm{m}^{-1}\right)$ & & & \\
\hline $\begin{array}{l}\text { Nodes }\left(\times 10^{-3} \mu^{-2}\right) \\
\text { Ends }\left(\times 10^{-3} \mu^{-2}\right)\end{array}$ & $12.380^{* * *}$ & $6.016^{* * *}$ & $3.244^{* * *}$ \\
\hline Pores $\left(\times 10^{-3} \mu \mathrm{m}^{-2}\right)$ & & $-2.662^{* *}$ & \\
\hline Adjusted $\mathrm{R}^{2}$ & 0.981 & 0.960 & 0.973 \\
\hline SE of the estimate & 0.143 & 0.197 & 0.177 \\
\hline
\end{tabular}

${ }^{1} \mathrm{LM}=$ light microscopy $\mathrm{TEM}=$ transmission electron microscopy; $\mathrm{A}_{\mathrm{A}}=$ area fraction of the nonprotein phase; $\mathrm{P}_{\mathrm{L}}=$ half of surface/volume ratio; $\mathrm{L}_{3}=$ mean intercept length.

${ }^{2} \mathrm{WSN}=$ water-soluble nitrogen; TCASN $=$ trichloroacetic acid-soluble nitrogen; PTASN $=$ phosphotungstic acid-soluble nitrogen.

${ }^{3}$ Twelve true replicates $\times 6$ analytical replicates.

${ }^{4}$ Twelve true replicates $\times 9$ analytical replicates

${ }^{*} P<0.05 ;{ }^{* *} P<0.01 ;{ }^{* * *} P<0.001$ : significant correlation.

general, to be good candidates for attempts to relate the extent of proteolysis and the texture to the cheese microstructure. It can be stated that a decrease in $A_{A}$, $\mathrm{P}_{\mathrm{L}}$, length, nodes, and ends is closely associated with an increase in firmness, fracturability, Young's modulus, and proteolysis, but with a decrease in springiness and adhesiveness. Moreover, the viewing fields and sections (only accessible by LM) affected significantly the microstructural parameters analyzed, so sampling at the field of view level is preferable to sampling at the cheese block level, or even at the cheese section level.

\section{ACKNOWLEDGMENTS}

The authors are grateful to Susana Caldas (Centre of Biotechnology and Fine Chemistry, CBQF, Porto, Portugal) for valuable discussions pertaining to image analysis, and Rui Fernandes (Instituto de Biologia Celular e Molecular, IBMC, Porto, Portugal) for technical assistance with electron microscopy. Financial support for P. J. M. Reis was provided by a PhD fellowship (ref. BD/19752/99), granted by FCT within program PRAXIS XXI (Portugal), under the supervision of F. X. Malcata. F. X. Malcata also acknowledges availabil- ity of laboratory premises and analytical equipment at $\mathrm{CBQF}$ and IBMC, for performance of analytical work.

\section{REFERENCES}

Auty, M. A. E., B. T. O'Kennedy, P. Allan-Wojtas, and D. M. Mulvihill. 2005. The application of microscopy and rheology to study the effect of milk salt concentration on the structure of acidified micellar casein systems. Food Hydrocoll. 19:101-109.

Baddeley, A. J., H. J. G. Gundersen, and L. M. Cruz-Orive. 1986. Estimation of surface area from vertical sections. J. Microsc 142:259-276.

Breuil, P., and J.-F. Meullenet. 2001. A comparison of three instrumental tests for predicting sensory texture profiles of cheese. J. Texture Stud. 32:41-55.

Buffa, M. N., A. J. Trujillo, M. Pavia, and B. Guamis. 2001. Changes in textural, microstructural, and colour characteristics during ripening of cheeses made from raw, pasteurized or high-pressuretreated goats' milk. Int. Dairy J. 11:927-934.

Creamer, L. K., and N. F. Olson. 1982. Rheological evaluation of maturing Cheddar cheese. J. Food Sci. 47:631-636.

Datta, A. K., S. Sahin, G. Sumnu, and S. Ö. Keskin. 2007. Porous media characterization of breads baked using novel heating modes. J. Food Eng. 79:106-116.

Fox, P. F., J. Law, P. L. H. McSweeney, and J. Wallace. 1993. Biochemistry of cheese ripening. Pages 389-438 in Cheese: Chemistry, Physics and Microbiology. P. F. Fox, ed. Chapman \& Hall, London, UK.

Fox, P. F., and P. L. H. McSweeney. 1996. Proteolysis in cheese during ripening. Food Rev. Int. 12:457-509. 
Funebo, T., L. Ahrné, S. Kidman, M. Langton, and C. Skjöldebrand. 2000. Microwave heat treatment of apple before air dehydrationEffects on physical properties and microstructure. J. Food Eng. 46:173-182.

Guinee, T. P., M. A. E. Auty, and M. A. Fenelon. 2000. The effect of fat content on the rheology, microstructure and heat-induced functional characteristics of Cheddar cheese. Int. Dairy J. 10:277288.

Guinee, T. P., P. D. Pudja, W. D. Reville, D. Harrington, E. O. Mulholland, M. Cotter, and T. M. Cogan. 1995. Composition, microstructure and maturation of semi-hard cheeses from high protein ultrafiltered milk retentates with different levels of denatured whey protein. Int. Dairy J. 5:543-568.

Gundersen, H. J. G., P. Bagger, T. F. Bendtsen, S. M. Evans, L. Korbo, N. Marcussen, A. Moller, K. Nielsen, J. R. Nyengaard, B. Pakkenberg, F. B. Sorensen, A. Vesterby, and M. J. West. 1988a. The new stereological tools: Disector, fractionator, nucleator and point sampled intercepts and their use in pathological research and diagnosis. APMIS 96:857-881.

Gundersen, H. J. G., T. F. Bendtsen, L. Korbo, N. Marcussen, A. Moller, K. Nielsen, J. R. Nyengaard, B. Pakkenberg, F. B. Sorensen, A. Vesterby, and M. J. West. 1988b. Some new, simple and efficient stereological methods and their use in pathological research and diagnosis. APMIS 96:379-394.

Hermansson, A.-M., M. Langton, and N. Lorén. 2000. New approaches to characterizing food microstructures. MRS Bull. 25:30-36.

Johnston, K. A., F. P. Dunlop, C. J. Coker, and S. M. Wards. 1994. Comparisons between the electrophoretic pattern and textural assessment of aged Cheddar cheese made using various levels of calf rennet or microbial coagulant (Rennilase 46L). Int. Dairy J. $4: 303-327$.

Kheader, E. E., J. F. Vachon, P. Paquin, and I. Fliss. 2002. Effect of dynamic high pressure on microbiological, rheological and microstructural quality of Cheddar cheese. Int. Dairy J. 12:435-446.

Langton, M., and A.-M. Hermansson. 1996. Image analysis of particulate whey protein gels. Food Hydrocoll. 10:179-191.

Langton, M., E. Jordansson, A. Altskär, C. Sørensen, and A.-M. Hermansson. 1999. Microstructure and image analysis of mayonnaises. Food Hydrocoll. 13:113-125.

Liu, R. X., J. Kuang, Q. Gong, and X. L. Hou. 2003. Principal component regression analysis with SPSS. Comput. Methods Programs Biomed. 71:141-147.

Lorén, N., M. Langton, and A.-M. Hermansson. 1999. Confocal laser scanning microscopy and image analysis of kinetically trapped phase-separated gelatin/maltodextrin gels. Food Hydrocoll. 13:185-198.

Macedo, A. C., M. L. Costa, and F. X. Malcata. 1996. Changes in the microflora of Serra cheese: Evolution throughout ripening time, lactation period and axial location. Int. Dairy J. 6:79-94.

Macedo, A. C., and F. X. Malcata. 1997. Secondary proteolysis in Serra cheese during ripening and throughout the cheese-making season. Z. Lebensm. Unters. Forsch. A 204:173-179.

Macedo, A. C., F. X. Malcata, and J. C. Oliveira. 1993. The technology, chemistry, and microbiology of Serra cheese: A review. J. Dairy Sci. 76:1725-1739.

Mouton, P. R. 2002. Principles and Practices of Unbiased Stereology: An Introduction for Bioscientists. John Hopkins University Press, Baltimore, MD.

O'Mahony, J. A., M. A. E. Auty, and P. L. H. McSweeney. 2005. The manufacture of miniature Cheddar-type cheeses from milks with different fat globule size distributions. J. Dairy Res. 72:338-348.

O'Reilly, C. E., P. M. Murphy, A. L. Kelly, T. P. Guinee, M. A. E. Auty, and T. P. Beresford. 2002. The effect of high pressure treatment on the functional and rheological properties of Mozzarella cheese. Innov. Food Sci. Emerg. Technol. 3:3-9.
Olsson, C., M. Langton, and A.-M. Hermansson. 2002. Microstructures of $\beta$-lactoglobulin/amylopectin gels on different length scales and their significance for rheological properties. Food Hydrocoll. $16: 111-126$.

Özer, B. H., R. K. Robinson, and A. S. Grandison. 2003. Textural and microstructural properties of Urfa cheese (a white-brined Turkish cheese). Int. J. Dairy Technol. 56:171-176.

Parker, M. L., P. A. Gunning, A. C. Macedo, F. X. Malcata, and T. F. Brocklehurst. 1998. The microstructure and distribution of micro-organisms within mature Serra cheese. J. Appl. Microbiol. 84:523-530.

Pavia, M., B. Guamis, A. J. Trujillo, M. Capellas, and V. Ferragut. 1999. Changes in microstructural, textural and colour characteristics during ripening of Manchego-type cheese salted by brine vacuum impregnation. Int. Dairy J. 9:91-98.

Reis, P. M., P. L. Lourenço, A. Domingos, A. F. Clemente, M. S. Pais, and F. X. Malcata. 2000. Applicability of extracts from Centaurea calcitrapa in ripening of bovine cheese. Int. Dairy J. 10:775-780.

Reynolds, E. S. 1963. The use of lead citrate at high $\mathrm{pH}$ as an electron opaque stain in electron microscopy. J. Cell Biol. 17:208-212.

Rodríguez, J., T. Requena, J. Fontecha, H. Goudédranche, and M. Juárez. 1999. Effect of different membrane separation technologies (ultrafiltration and microfiltration) on the texture and microstructure of semihard low-fat cheeses. J. Agric. Food Chem. $47: 558-565$.

Russ, J. C. 2005. Image Analysis of Food Microstructure. CRC Press, Boca Raton, FL.

Sipahioglu, O., V. B. Alvarez, and C. Solano-Lopez. 1999. Structure, physico-chemical and sensory properties of Feta cheese made with tapioca starch and lecithin as fat mimetics. Int. Dairy J. 9:783789.

Skriver, A., M. B. Hansen, and K. B. Qvist. 1997. Image analysis applied to electron micrographs of stirred yogurt. J. Dairy Res. 64:135-143.

Smith, A. K., H. D. Goff, and Y. Kakuda. 1999. Whipped cream structure measured by quantitative stereology. J. Dairy Sci. 82:16351642

Tamime, A. Y., D. D. Muir, M. E. Shenana, M. Kalab, and A. H. Dawood. 1999. Processed cheese analogues incorporating fat-substitutes. 2. Rheology, sensory perception of texture and microstructure. Lebensm. Wiss. Technol. 32:50-59.

Tavaria, F. K., I. Franco, F. J. Carballo, and F. X. Malcata. 2003. Amino acid and soluble nitrogen evolution throughout ripening of Serra da Estrela cheese. Int. Dairy J. 13:537-545.

Tavaria, F. K., and F. X. Malcata. 1998. Microbiological characterization of Serra da Estrela cheese throughout its Appéllation d'Origine Protégée region. J. Food Prot. 61:601-607.

Tavaria, F. K., P. J. M. Reis, and F. X. Malcata. 2006. Effect of dairy farm and milk refrigeration on microbiological and microstructural characteristics of matured Serra da Estrela cheese. Int. Dairy J. $16: 895-902$.

Thorvaldsson, K., M. Stading, K. Nilsson, S. Kidman, and M. Langton. 1999. Rheology and structure of heat-treated pasta dough: Influence of water content and heating rate. Lebensm. Wiss. Technol. 32:154-161.

Watkinson, P., C. Coker, R. Crawford, C. Dodds, K. Johnston, A. McKenna, and N. White. 2001. Effect of cheese $\mathrm{pH}$ and ripening time on model cheese textural properties and proteolysis. Int. Dairy J. 11:455-464.

Wium, H., P. S. Pedersen, and K. B. Qvist. 2003. Effect of coagulation conditions on the microstructure and the large deformation properties of fat-free Feta cheese made from ultrafiltered milk. Food Hydrocoll. 17:287-296. 